\title{
Present Perfect: Effects of Learning Environment
}

\section{Sato Watanabe \\ Keio University}

\section{Reference Data:}

Watanabe, S. (2019). Present perfect: Effects of learning environment. In. P. Clements, A. Krause, \& R. Gentry (Eds.), Teacher efficacy, learner agency. Tokyo: JALT.

https://doi.org/10.37546/JALTPCP2019-30

In this study I investigated the influence of Japanese EFL environments on the acquisition of the English present perfect form by comparing Japanese native speakers who have lived abroad and returned to live in Japan (JRs) and those who have never been abroad (JNRs) with a control group of native English speakers (NESs). In Japanese classrooms, the present perfect is usually taught by focusing on three translation categories (completion, duration, and experience) along with certain durative adverbials (e.g., already, yet, and since). Using a gap-fill test, I looked at how Japanese-English translation styles, lexical aspect, and the presence of adverbials can affect learners' use of the English present perfect. Results show more accurate present perfect use by JRs and NESs and the positive influence of the presence of durative adverbials. Pedagogical implications include the need for provisions of contextual support in teaching present perfect in the classroom environment

本研究は、日本のEFL環境における指導法がどの上うに現在完了形の使用に影響を与えるのかを調查した。日本のEFL環 境では、現在完了形は完了・継続·経験の3用法に分類し日本語での説明を加えた指導がなされ、それれそれの用法に継続相 の副詞表現を関連づけて指䆃される場合が殁じである。このような指導法の影響を探るべく、海外経験のある日本語母語話者 (JR)、海外経験の無い日本語母語話者 (JNR)、英語母語話者(NES)の3種類の参加者を対象に、現在完了形の義務的文脈内 での使用に違いがあるのかを比較した。その結果、JRPNESが現在完了形を使用した文脈においてJNRは過去形や現在形を 使亏傾向が見られた。また、継続相の副詞が確認できる文脈では、JNRもJRも現在完了形使用がより正確になるなどの共通点 も見られた。教育的示唆として、現在完了形使用が適切となるような文脈に関する肯定証拠を学習者に与える必要性などが提
案される。 earning environments are one of the main factors underlying the success or failure $\checkmark$ of second language acquisition and have been the subject of discussion in many studies (Norris \& Ortega, 2000). The effects of learning environments on pragmatics have been one of the most debated topics in an extensive body of existing literature (e.g., DeKeyser, 1991; Freed, Segalowitz, \& Dewey, 2004; Taguchi, 2008). Research has also been conducted on the influence of learning environments on the acquisition of grammatical knowledge. Sun, Steinkrauss, Tendeiro, and de Bot (2016) investigated the effects of internal and external factors on the acquisition of English receptive vocabulary, productive vocabulary, and receptive grammar. According to this study, the quality and quantity of English teaching input from teachers and English use in the classroom were strong predictors of the acquisition of all three. There was also strong influence by the learning environment.

However, as Collins (2004) pointed out, there is a lack of studies that focus on differences in the acquisition of tense-aspect morphology by learners who have spent time abroad in the target language context versus those who have not. In other words, more studies comparing the use of tense-aspect morphology by learners with the same L1 but with different English learning backgrounds are necessary. Most of the research on the acquisition of tense-aspectual morphology is concerned with the validity of the aspect hypothesis (Andersen \& Shirai, 1996), which predicts the effect of each verb's semantic properties on its acquisition. Based on this hypothesis, researchers have investigated the order in which tense-aspectual morphology is acquired by English learners from a variety of language backgrounds (e.g., Bardovi-Harlig, 1997). Many studies conclude that the verbs' semantic representations affect the acquisition and use of tense-aspectual expressions (Shirai, 2009; Uno, 2014). However, there is relatively little research on the effects of the classroom environment or the mode of language. Moreover, existing literature has provided few suggestions for how the acquisition of the English present perfect in the Japanese classroom environment can be enhanced (Uno, 2014). 
In this study I investigated the extent to which the learning environment influences Japanese EFL learners' use of the present perfect and how this differs between Japanese students who have spent significant time studying or living abroad (returnees) and those who have not (nonreturnees). With the study I hope to not only contribute to the existing body of research regarding the acquisition of English tense-aspectual expressions but also suggest some possible opportunities for teachers to enhance the effectiveness of their teaching approach to the English present perfect.

\section{Background}

The Acquisition of Tense-Aspect Morphology and the Aspect Hypothesis

The acquisition of tense-aspectual expressions has been an interest of many SLA researchers, resulting in a substantial body of research on the topic (Bardovi-Harlig, 1997; Collins, 2004). Many of these studies have focused on the effect of lexical aspects, which refer to the semantic implication of verbs. For example, some verbs have an inherent endpoint (e.g., Mark won the match); others do not (e.g., Ben and Julia danced). Some verbs are punctual (e.g., George jumped), and others express states (e.g., Lauren loves to read). Vendler (1967/1957) categorized verbs into four different groups based on their lexical aspect: state, activity, accomplishment, and achievement. Using these categorizations, an extensive amount of research on the acquisition of tense-aspect morphology has been conducted (e.g., Andersen \& Shirai, 1994; Robison, 1995; Shirai, 2009).

The empirical validity of the aspect hypothesis has been supported by many studies, such as Bardovi-Harlig (1997), which examined common traits in the acquisition patterns of English tense-aspect morphology for English learners from a variety of backgrounds. By comparing the usage of tense-aspectual markers for verbs with different lexical aspects, Uno (2014) illustrated the effect of the semantic properties of verbs on Japanese EFL learners' acquisition of the present perfect. Uno reported that Japanese learners tended to associate the present perfect with telic verbs (i.e., accomplishment and achievement verbs). In particular, these studies have demonstrated that the lexical aspect influences the acquisition of $\mathrm{L} 2$ tense-aspect morphology.

Some studies have also focused on factors other than the influence of lexical aspect on learning, such as the influence of prior L1 knowledge. Gabriele (2009) conducted a bidirectional study on English and Japanese language learners, showing that these two groups showed differences in how accurate they were at using imperfective morphology. English students studying Japanese showed more accurate use of the imperfective morphology than did the Japanese students studying English. This study suggests that differences in morphological complexity influence learners performance in using tense-aspectual expressions. Comparisons between French and Japanese learners of English were also conducted by Collins (2004) and show that the differences in the use of the present perfect in English may be caused by the different tense-aspectual characteristics of the French and Japanese languages. However, there has been relatively little investigation on the influence of the Japanese EFL learning environment or extra-curricular English exposure on the acquisition of the English present perfect by Japanese learners.

Instruction on the Present Perfect in the Japanese Classroom Context

The grammar-translation method is still widely used to teach languages in Japanese public schools (Hamada, 2011), which may lead to many Japanese teachers of English using Japanese translations when teaching the present perfect. One approach to teaching the present perfect via the grammar-translation method separates the usage of the present perfect into three different categories: completion, duration, and experiential. For each category, a specific Japanese translation is associated. The translation for the completion category is -shite shimatta/shita, the duration category is -shite iru, and the experiential category is -shita koto ga aru.

In addition, particular durative adverbials are associated with each categorization, making it easier for the learners to identify contexts in which using present perfect would be appropriate. For example, expressions such as already and yet are associated with the completion category (e.g., Tom has already finished his homework). Since and for are associated with the duration category (e.g., Mary has been married to Tom since 2010). Once and twice are associated with the experiential category (e.g., Kate has visited Paris twice).

This style of the grammar-translation method may limit students' opportunities to engage in conversational activities in English in class (Kikuchi \& Browne, 2009). As Hamada (2011) pointed out, the Japanese English education system is heavily influenced by the necessity for the students to pass university entrance exams. As a consequence, there is often an emphasis on teaching methods that are focused on university entrance exams, which prioritize the memorization of English grammar rather than providing communication-based exposure to the language.

\section{Methodology}

The purpose of this study was to provide English teachers with possible methods to enhance Japanese learners' acquisition of the English present perfect. The extent to 
which the time spent abroad in a native-speaker context and how student exposure to

English affects the acquisition and use of English present perfect was investigated.

The following research questions were set:

RQ1: Do returnee students show more accurate use of the present perfect compared to students who have not spent time abroad?

RQ2: How do any observed differences relate to lexical aspect or Japanese translation?

RQ3: How does the present perfect use by the two Japanese participant groups compare to that of native speakers of English?

\section{Participants}

Sixty Japanese students (aged 18 to 22) who attend a Japanese university participated in this study. Thirty-two of these participants, who had spent 2 to 6 years living in English speaking countries, were categorized as returnees (JRs). Twenty-eight participants, who had never lived abroad or attended international school, were categorized as nonreturnees (JNRs). An additional 16 native speakers of English (NESs) were used as a control group. All of the participants were asked to complete a gap-fill test in order to examine patterns in verb conjugation accuracy according to the tense or aspect that is required.

Whereas JNRs are required to receive 6 years of mandatory English education (MEXT, 2019), JRs receive English education in native-speaker environments. This difference in learning context is also likely augmented by experience outside the formal learning situation. Of all JNR participants, $36.2 \%$ reported having opportunities to regularly use English outside of class time, such as casual conversations with friends and family, cram schools, or English conversation lessons. All JRs reported such opportunities.

\section{Material and Data Collection}

A gap-fill test, which consisted of a passage with missing words that the reader has to fill in, was used in this study (see Appendix.) This method has been used in several studies (Ayoun \& Salaberry, 2008; Collins, 2004; Uno, 2014) to investigate the acquisition of tense and aspectual morphology. The test material consisted of two passages: a story and an interview. The verb forms in some sentences in the passages were left blank, and the participants were asked to conjugate the base form of the verb given for each of these. Following previous studies (e.g., Uno, 2014), in order to reduce cognitive load, if there were fewer than four words between two verbs, only one of them was removed.
All of the participants received a verbal explanation about the test and an outline of how the information gathered from the test would be used. All participants gave written consent to participate in this study, and this study was given clearance by the university's research review committee.

The passages used in the gap-fill test were reviewed by several native English speakers to check the validity of the test. To establish the reliability of the gap-fill test battery, a Cronbach's alpha was calculated. This produced an alpha of .810, suggesting high reliability. The participants were given 40 minutes during class time to complete the test.

\section{Analysis}

Each target item was categorized based on its telicity (whether or not the verb has an inherent endpoint in its meaning), its Japanese categorization (as completion, duration, or experience), and/or whether or not the context included durative adverbials. Verb telicity was categorized following Uno (2014): state and activity verbs were categorized as atelic verbs; accomplishment and achievement verbs were labeled telic.

For each categorization, the percentage of the correct usage of the present perfect in the gap-fill test was calculated. The results were checked by native English speakers and compared with the NES control group. Tables 1 and 2 show examples of verbs for each category.

\section{Table 1. Examples of Gap-Fill Test Verbs (Japanese Categorization)}

\begin{tabular}{ll}
\hline Verb type & Example \\
\hline Completion & decide, release, lose \\
Duration & keep, own, support \\
Experiential & sail, meet, have \\
\hline
\end{tabular}

Table 2. Examples of Gap-Fill Test Verbs (Telicity)

\begin{tabular}{ll}
\hline Verb type & Example \\
\hline Telic & decide, release, win \\
Atelic & keep, support, have \\
\hline
\end{tabular}




\section{Results}

The Japanese participants' TOEFL ITP scores were gathered in order to compare the English proficiency between the two groups. The JNRs' mean score was 499.09 ( $S D$ $=11.10)$, and the JRs' mean score was $504.18(S D=10.93)$. No statistically significant difference between the two groups' TOEFL scores was found $(t=-1.55$, n.s.), so it is reasonable to assume that any differences in the JRs' and the JNRs' performance on the gap-fill test were not significantly influenced by differences in English proficiency per se.

Table 3 shows the ANOVA results of correct use of present perfect telic and atelic verbs between the three participant groups.

Table 3. ANOVA of Correct Use of Present Perfect by Participant Group (\%)

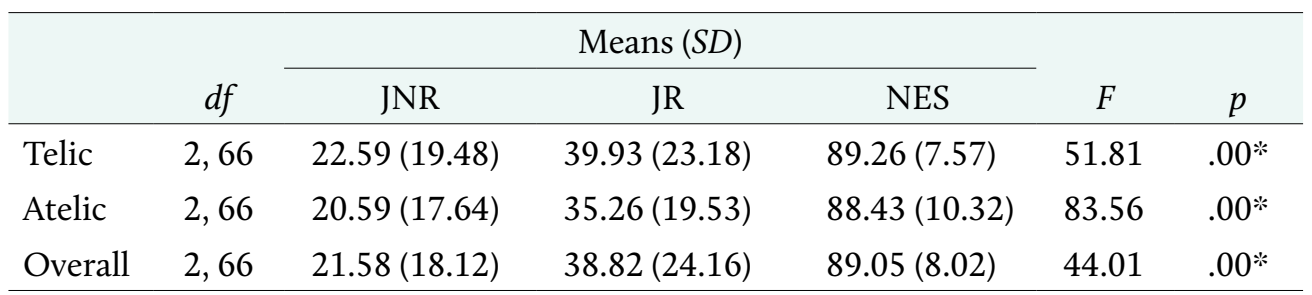

Note. JNR = Japanese English learners who have never been abroad $(n=28) ; \mathrm{JR}=$ Japanese native speakers who have lived abroad and returned to live in Japan $(n=32)$; NES = Native English speakers $(n=16)$.

$* p<.01$

Overall, the participants tended to be more accurate in their use of the present perfect for contexts in which the verb was telic rather than atelic. However, paired, two-tailed $t$ tests showed these differences were not statistically different, suggesting a limited effect of the verbs' telicity (JNR $t(2,66)=-2.797$, n.s.; JR $t(2,66)=1.116$, n.s.).

The results of Tukey HSD comparisons show statistically significant differences $(p<$ 0.05 ) for the mean use of telic verbs, atelic verbs, and the overall results, respectively, between all three of the participant groupings.

Table 4 shows the mean percentage and the standard deviation of the accuracy of present perfect use depending on the presence of durative adverbials.
Table 4. Accuracy of Present Perfect Depending on the Presence of Durative Adverbials (\%)

\begin{tabular}{|c|c|c|c|c|c|}
\hline & & \multicolumn{2}{|c|}{ Means $(S D)$} & \multirow[b]{2}{*}{$t$} & \multirow[b]{2}{*}{$p$} \\
\hline & & $\begin{array}{l}\text { with durative } \\
\text { adverbials }\end{array}$ & $\begin{array}{c}\text { without durative } \\
\text { adverbials }\end{array}$ & & \\
\hline \multirow[t]{2}{*}{ JNR } & telic & $33.38(24.95)$ & $10.00(20.95)$ & 2.04 & $.00 *$ \\
\hline & atelic & $30.22(21.29)$ & $9.38(18.31)$ & 1.67 & $.00 * *$ \\
\hline \multirow[t]{2}{*}{$J R$} & telic & $54.14(26.26)$ & $22.86(25.94)$ & 9.03 & $.00 *$ \\
\hline & atelic & $46.39(19.48)$ & $22.14(25.15)$ & 5.91 & $.00 * *$ \\
\hline \multirow[t]{2}{*}{ NES } & telic & $87.88(14.37)$ & $91.11(9.94)$ & 0.44 & .33 \\
\hline & atelic & $93.45(7.42)$ & $80.00(14.77)$ & 1.69 & .06 \\
\hline
\end{tabular}

Note. JNR = Japanese English learners who have never been abroad $(n=28)$; JR = Japanese native speakers who have lived abroad and returned to live in Japan $(n=32)$; NES = Native English speakers $(n=16)$.

$* p<0.01, * * p<0.001$

Both the JR and JNR groups showed significantly greater accuracy of present perfect use for durative adverbials than nondurative adverbials, particularly for atelic verbs. Furthermore, both the JNR and JR participants were noticeably more likely to use the present perfect accurately for items that entailed durative adverbials. However, for telic verbs and atelic verbs, respectively, the NES participants showed no statistically significant difference in present perfect usage between items, with or without adverbials.

Table 5 shows the results of the ANOVA for the use of the present perfect depending on how each verb category would be translated into Japanese. 
Table 5. ANOVA of Correct Present Perfect Use by Japanese Translation Category (\%)

\begin{tabular}{|c|c|c|c|c|c|c|}
\hline & & \multicolumn{3}{|c|}{ Mean $(S D)$} & \multirow[b]{3}{*}{$F$} & \multirow[b]{3}{*}{$p$} \\
\hline & \multirow[b]{2}{*}{$d f$} & \multicolumn{2}{|c|}{ Non-durative } & \multirow{2}{*}{$\begin{array}{c}\text { Durative } \\
\text { Duration } \\
\text {-shita koto ga } \\
\text { aru }\end{array}$} & & \\
\hline & & $\begin{array}{c}\text { Completion } \\
\text {-shitte-shimatta/ } \\
\text { shita }\end{array}$ & $\begin{array}{c}\text { Experiential } \\
\text {-shite iru }\end{array}$ & & & \\
\hline JNR & 2,93 & $23.23(20.65)$ & $24.29(24.28)$ & $19.35(17.31)$ & 0.46 & 0.63 \\
\hline$J R$ & 2,81 & $39.14(21.81)$ & $39.93(28.73)$ & $37.86(21.32)$ & 0.52 & 0.95 \\
\hline NES & 2,45 & $91.67(14.43)$ & $76.79(20.67)$ & 88.33 (19.23) & 0.85 & 0.44 \\
\hline
\end{tabular}

Note. JNR = Japanese English learners who have never been abroad $(n=28)$; JR = Japanese native speakers who have lived abroad and returned to live in Japan $(n=32)$; NES = Native English speakers $(n=16)$.

As shown in Table 5, the JNR participants showed the most accurate use of the present perfect in the experiential category and least accurate use in the completion category. On the other hand, the JR participants showed greater accuracy in the completion and experiential categories and less accuracy in the duration category. The NES showed a somewhat similar pattern of the use of the present perfect in that they showed the highest accuracy in the completion category and the least in experiential. However, Tukey HSD comparisons showed no statistically significant difference for the mean percentage of the present perfect use between the three Japanese categorizations for any of the participant groups.

\section{Discussion}

As can be seen from the results, the JRs and the JNRs showed differences in their use of the present perfect in that the JNR participants tended to use present perfect less frequently than the JRs when they could not rely on Japanese translations (as was the case in the gap-fill test). In this regard, the JR participants showed a more similar pattern of usage of the present perfect to the NESs. When the participants had to complete a verb form that was collocated with a durative adverbial, the JNR participants showed greater accuracy in present perfect use compared to the JRs. This supports Uno (2014) who reported an increase of correct present perfect usage for instances when the verb patterns entailed a durative adverbial. When considering the effect of lexical aspect per se, there seems to be relatively little influence on the JR and JNR participants. Both groups were more accurate at using the present perfect with telic verbs than atelic verbs. However, as can be seen in Table 3, the increase was relatively small, which suggests that lexical aspect may have a relatively small influence on accuracy. This implies that having studied abroad in an English-speaking country has little to do with the capacity to correctly use the present perfect for telic verbs. This is in line with other studies' findings, in that the correct use of tense-aspectual expressions is influenced not only by the lexical aspect but also by other factors such as prior L1 knowledge (Ayoun \& Salaberry, 2008; Collins, 2004)

Differences in the use of the present perfect among different proficiency groups may be explained by several factors. As can be seen in Table 4, the Japanese learners, particularly the JNR participants, showed less accurate use of the present perfect for those verb forms that express duration. This may be an outcome of the way in which lexical aspects influence learners' use of the present perfect. Verb collocations that express duration suggest an imperfective sense, but collocations that express experiential and completion suggest a perfective sense. As the aspect hypothesis (Shirai \& Andersen, 1995) indicates, due to the influence of lexical aspects, the acquisition of perfective morphology occurs earlier than imperfective morphology. For example, it is easier for telic verbs to be associated with perfective morphology, because telic verbs inherently imply an endpoint to an action or state. The perfective aspect has a similar implication, meaning that telic verbs are more commonly used as perfective forms. As such, it takes more time for atelic verbs to be associated with the perfective morphology, because the atelic verbs do not represent an inherent endpoint and are therefore less commonly used to express perfectives (Shirai \& Andersen, 1995). According to Ayoun and Salaberry (2008), the emergence of the morphology can then lead to the use of it as tense-aspectual markers. As a consequence, the earlier the acquisition of a particular morphology, the earlier the learners become able to put it into use. The participants in this study seem to have demonstrated support for the aspect hypothesis through more accurate use of the present perfect for the more common perfective morphology.

In this study, within the JRs and the JNRs, there was no statistically significant difference in the use of the present perfect between telic verbs and atelic verbs. However, within the JR and the JNR groups, the difference between the use of the verb form between items that do and do not entail durative adverbials was statistically significant. This suggests that, among Japanese English-language learners, the effect of the presence of durative adverbials in contexts was a more significant factor than verb telicity. As both 
JRs and JNRs showed a statistically significant increase in the correct usage of the present perfect with durative adverbials, there is an implication that the presence of durative adverbials influences participant accuracy for this verb form. However, there was little observable difference between the NESs' use of the present perfect in contexts with or without durative adverbials, so the presence of durative adverbials may not make a large difference in the correct usage of the present perfect for NESs.

Looking closer at the effect of durative adverbials, the number of opportunities the participants reported having had to use English outside the classroom context may be one factor that affected accuracy. The JRs showed more correct present perfect usage than the JNRs, as can be seen in Tables 4 and 5 . This may be because the JRs indicated that they had had more exposure to English outside of class time and thus are likely to have had greater exposure to grammatically correct usage as well as explicit feedback from native speakers on their accurate use of the present perfect in real-life contexts. This may have led to better overall performance (see Iwashita, 2003; Strapp, Helmick, Tonkovich, \& Bleakney, 2011). The JRs may have also been able to draw on a broader tacit understanding of grammar in the gap-fill test. Therefore, the difference in correct usage may be a consequence of the observed difference of the opportunities to engage in L2 use in contexts where English is the native language.

\section{Conclusion, Implications, and Limitations}

In this study I examined whether significant amounts of time living abroad affect the acquisition and use of the present perfect. The results show that the use of the present perfect is influenced not only by the effect of lexical aspect and how these verb forms are translated into Japanese but also by the presence or absence of durative adverbials. Exposing EFL learners to naturalistic uses of this verb form may therefore be a more useful aid in facilitating the acquisition of verb-form usage than methods that are geared towards test-like contexts. This latter kind of EFL classroom environment is perhaps less likely to expose learners to contextualized examples that illustrate and encourage grammatically correct uses of the present perfect.

In order to facilitate contextualized learning, teachers could underline or highlight examples where the present perfect is used in their handouts or student textbooks. This can help to direct the learners' attention to the form and usage of the present perfect (Issa \& Morgan-Short, 2018). To this end, teachers could also use role-playing activities or encourage students to engage in real-life situations outside the classroom where using the present perfect is appropriate if not necessary. This could include tasks such as talking about past events that have had an influence on present life.
This study could be enhanced by examining specific differences in each participant groups' educational backgrounds. This could include measures such as whether and how much they had received explicit instruction on present-perfect forms and uses as well as the amount of in-class time provided for lecture-style instructions and/or English conversational activities. This study was focused on the effects of the amount of exposure to and opportunities for usage of English in different learning environments. Collecting other information, such as the volume of explicit learning of durative adverbials and how this is associated with use of the present perfect as well as categorical translation to Japanese, may increase the explanatory power of future study. Future research may also look deeper into the influence of grammar-translation-based instructional methods when under more specific research conditions, such as a durative adverbials instructional method, and how this cues verb-form usage.

\section{Bio Data}

Sato Watanabe is a master student at Keio University, studying applied linguistics. Her current interests include second language acquisition, language education, and English instructional methods. <char11143@keio.jp>

\section{References}

Andersen, R. W., \& Shirai, Y. (1994). Discourse motivations for some cognitive acquisition principles. Studies in Second Language Acquisition, 16(2), 133-156. https://doi.org/10.1017/S0272263100012845

Andersen, R. W., \& Shirai, Y. (1996). The primacy of aspect in first and second language acquisition: The pidgin-creole connection. In W. C. Ritchie \& T. K. Bhatia (Eds.), Handbook of Second Language Acquisition (pp. 527-570). San Diego, CA: Academic Press. https://doi.org/10.1016/b978-012589042-7/50018-9

Ayoun, D., \& Salaberry, M. R. (2008). Acquisition of English tense-aspect morphology by advanced French instructed learners. Language Learning, 58(3), 555-595. https://doi.org/10.1111/j.1467-9922.2008.00450.x

Bardovi-Harlig, K. (1997). Another piece of puzzle: The emergence of present perfect. Language Learning, 47(3), 375-422. https://doi.org/10.1111/0023-8333.00015

Collins, L. (2004). The L2 acquisition of tense-aspect morphology. Studies in Second Language Acquisition, 26(4), 622-624. https://doi.org/10.1017/s0272263104240049

DeKeyser, R. (1991). Foreign language development during a semester abroad. In B. F. Freed (Ed.), Foreign language acquisition research and the classroom. (pp.104-119). Lexington, MA: D. C. Heath. 
Freed, B. F., Segalowitz, N., \& Dewey, D. (2004). Context of learning and second language fluency in French: Comparing regular classroom, study abroad, and intensive domestic immersion programs. Studies in Second Language Acquisition, 26, 277-303. https://doi.org/10.1017/s0272263104262064

Gabriele, A. (2009). Transfer and transition in the SLA of aspect: A bidirectional study of learners of English and Japanese. Studies in Second Language Acquisition, 31(3), 371-402. https://doi.org/10.1017/s0272263109090342

Hamada, Y. (2011). Different demotivators for Japanese junior high and high school learners. Journal of Pan-Pacific Association of Applied Linguistics, 15(1), 15-38. Retrieved from https://files. eric.ed.gov/fulltext/EJ939938.pdf

Issa, B. I., \& Morgan-Short, K. (2018). Effects of external and internal attentional manipulations on second language grammar development: An eye-tracking study. Studies in Second Language Acquisition, 41(2), 389-417. https://doi.org/10.1017/S027226311800013X

Iwashita, N. (2003). Negative feedback and positive evidence in task-based interaction. Studies in Second Language Acquisition, 25(1), 1-36. https://doi.org/10.1017.S0272263103000019

Kikuchi, K., \& Browne, C. (2009). English educational policy for high schools in Japan: Ideals vs. reality. RELC Journal, 40(2), 172-191. https://doi.org/10.1177/0033688209105865

MEXT. (2019). 中学校学習指導要領 (平成29年度告示) 解説 外国語編 [Explanations on the course of study for junior high schools (issued 2017) for foreign language education]. Tokyo: MEXT. Retrieved April 3, 2020, from https://www.mext.go.jp/component/a_menu/education/micro detail/__icsFiles/afieldfile/2019/03/18/1387018_010.pdf

Norris, J. M., \& Ortega, L. (2000). Effectiveness of L2 instruction: A research synthesis and quantitative meta-analysis. Language Learning, 50(3), 417-528. https://doi.org/10.1111/0023-8333.00136

Robison, R. (1995). The aspect hypothesis revisited: A cross-sectional study of tense and aspect marking in interlanguage. Applied Linguistics, 16(3), 344-370. https://doi.org/10.1093/applin/16.3.344

Shirai, Y. (2009). Temporality in first and second language acquisition. In W. Klein \& P. Li (Eds.), The expression of time (pp. 167-194). https://doi.org/10.1515/9783110199031.167

Shirai, Y., \& Andersen, R. W. (1995). The acquisition of tense-aspect morphology: A prototype account. Language, 71(4), 743-762. https://doi.org/10.2307/415743

Strapp, C. M., Helmick, A. L., Tonkovich, H. M., \& Bleakney, D. M. (2011). Effects of negative and positive evidence on adult word learning. Language Learning, 61(2), 506-532. https://doi.org/10.1111/j.1467-9922.2010.00619.x

Sun, H., Steinkrauss, R., Tendeiro, J., \& de Bot, K. (2016). Individual differences in very young children's English acquisition in China: Internal and external factors. Bilingualism: Language and Cognition, 19(3), 550-566. https://doi.org/10.1017/S1366728915000243
Taguchi, N. (2008). The role of learning environment in the development of pragmatic comprehension: A comparison of gains between EFL and ESL learners. Studies in Second Language Acquisition, 30, 423-452. https://doi.org/10.1017/S0272263108080716

Uno, M. (2014). Lexical aspect in the use of the present perfect by Japanese EFL learners. International Review of Applied Linguistics in Language Teaching, 52(1), 31-57. https://doi.org/10.1515/iral-2014-0002

Vendler, Z. (1967). Verbs and times. In A. Vendler (Ed.), Linguistics and philosophy (pp. 97-121). Ithaca, NY: Cornell University Press. (Reprinted from Philosophical Review, 66, 143-160, 1957). https://doi.org/10.2307/2182371

\section{Appendix}

The Gap-Fill Test Used in the Study

氏名:

年齢:

\section{【1】}

( )内の動詞を、必要に応じて語形を変化させたり語を付け加えたりして、空闌を埋めてください。 Jenna and Drew are a happily married couple. They _ _ (own) their boat for 15 years. During that time, they___(sail) to many places for many times. They__(share) the love of the sea all their lives.

They___(sail) on the Pacific Ocean and on the Atlantic Ocean. They__(be) interested in the Hawaiian Islands for a long time, but they___not/have) the chance to actually go there yet.

Next year will___(be) their 15th wedding anniversary. They___(decide) to sail around the Hawaiian Islands, which had been their aspiration for years.

【2】

これは、架空のインタビュー番組“Talking with Amy”で行われたインタビューの様子です。0内の動 詞を、必要に応じて語形を変化させたり語を付け加えたりして、空欄を埋めてください。

AMY: Hello, and welcome to another episode of "Talking with Amy." Today, we (have) Steve McEwen as our guest. As a rock singer, he__(release) over 40 albums throughout his 35 year career. In addition, he_ (win) various awards for his contribution to the American music industry. I'm curious Steve, what__ (inspire) you to do all this? What (keep) you running for all these years? 
STEVE: Well Amy, I just__ (love) rock. All these years, I__(write) numerous songs, but I couldn't _ (do) it without the intense passion I_ (have) for music.

This strong emotion___(drive) me to convert my emotions into lyrics and melodies. AMY: Wow, I__ (be) simply amazed. Even after 35 years, you__(lose) none of your passion for music.

STEVE: No. Also, throughout my career, I__ (meet) lots of amazing people_fans, staffs, and so on. They__(support) me a lot, mostly in emotional ways. That_ (keep) me fighting, even through difficult times.

AMY: I'm sure you__(have) a lot of opportunities to meet new people in your long career. How many countries___you/visit)?

STEVE: About 40. Thanks to all the world tours, I _ (travel) to lots of places.

All the experience _ (have) a great impact on my career. I feel like I__(become) a better performer every time I__ (finish) a tour.

AMY: Well, you__(finish) your fifth Asia tour recently. It__(seem) like your performance. (be) as good as your original work. Is there anything special that you _____(do) to maintain your powerful voice?

STEVE: I__ (see) a vocal trainer, Tim, for 15 years. He__(help) me a lot with keeping my voice just like it _ (be) decades ago. Tim__ (advise) me to try lots of training methods, and all of them__(work) great on me so far. That's how I__(maintain) my voice over the years.

AMY: Your timeless work and effort__(be) truly inspiring to all of us.

I__(wish) you all the best for your next tour in Europe. Thank you for coming, Steve.

STEVE: Thank you. It_ (be) a pleasure talking with you. 